\title{
Substantiation of ways to reclaim the space of the previously mined-out quarries for the recreational purposes
}

\author{
Tursyn Kalybekov ${ }^{1}$, Manarbek Sandibekov ${ }^{1}$, Kanay Rysbekov ${ }^{1}{ }^{*}$, and Yryszhan Zhakypbek ${ }^{1}$ \\ ${ }^{1}$ Satbayev University, 22a Satpaeva St., 050013 Almaty, Republic of Kazakhstan
}

\begin{abstract}
Opencast fields mining leads to land disturbance when conducting mining operations and storing of overburden rocks. The timely reclaiming of the disturbed lands according to the legislation requirements is an immediate duty of the subsoil user. The reclamation of the previously mined-out space of quarries refers to an extremely important tasks of the mining enterprise. The use of water management direction in reclamation assumes the use of previously mined-out space of a quarry to create the water reservoir through various methods of rehabilitation. There are presented various ways of designing the coastal zone of the created artificial water reservoirs in the previously mined-out space of the quarries located worldwide, which are used for the recreational purposes. The various profiles of slopes of artificial water reservoirs in a quarry with more low gradients, suitable for swimming and recreation are shown. Designing of a coastal area on the site of a quarry, intended for water reservoirs, depends on the water level position in the created body of water. The water reservoir, as the lake of artificial origin, created on the former quarry site, is shown. The purpose of the article is to substantiate the methodological approaches and engineering solutions concerning reclamation of the mined-out space after the opencast mining for the recreational purposes.
\end{abstract}

\section{Introduction}

Opencast mining of mineral deposits is bound to disturbance of the considerable land resources during their operation. Therefore, according to legislation requirements, the subsoil users, when developing mineral deposits, are obliged to fulfil $[1,2]$ : remediation of disturbed lands, reclamation of their fertility, useful properties and timely involvement in economic circulation; to restore lands and natural objects disturbed by subsurface operations to a state suitable for further use. Natural resource users when carrying out operations on subsurface use, geological exploration, construction and other works have to $[3,4]$ : maintain the occupied allotments in the state suitable for their further proper use; carry out the reclamation of disturbed lands when performing mining operations.

The use of the previously mined-out space of a quarry as impounding reservoirs is an effective way to restore the lands disturbed by mining operations [5-7]. The reservoirs

\footnotetext{
* Corresponding author: k.rysbekov@,satbayev.university
} 
created in previously mined-out quarries do not demand expensive dams and are safer in exploitation due to the lack of water breakthrough danger. Besides, they usually occupy the smaller area per a unit of water volume in comparison with reservoirs in natural land surface subsidence. Further on, the possibility is created of complex use of a reservoir for water supply, irrigation, fish and recreational purposes.

When designing and organizing the territories for recreational purposes around previously mined-out area, the terrain profile is considered, which depends largely on the existing system of landscape and natural conditions. In this case, it is necessary to study its interrelations with structural components and to develop methods for harmonious inclusion of recreational facilities and valuable natural landscapes into the structure of the territory. The territory size, attendance, the prevailing types of leisure activity and remoteness from the settlement influence on the degree of the coast improvement of the previously minedout quarry. According to sanitary and hygienic requirements, special attention should be paid primarily to the formation of vegetation cover around the designed beach, maintaining favorable treatment and composition of water, as well as the landscaping and gardening the coast.

In terms of the recreational direction of lands and reclamation of the previously minedout areas, the work is carried out in the settlements of the disturbed land area occupied by city forests, public gardens, parks, urbanistic gardens, ponds, lakes, reservoirs, to the state suitable for use by the population of the specified objects for rest, tourism and sports activities [8]. In this regard, reclamation of the previously mined-out sites of a quarry meet the requirements of the existing normative documents for subsurface use.

The search for new ecologically and economically justified economic decisions allowing to reduce the environmental load and to restore ecological balance in the area of mining operations is an important task [9]. The rational direction when using the disturbed territories by means of reclamation, is creation on the territory of the mining enterprise of a recreation area, sports facilities, sites for special and public use [10].

After water management reclamation of a quarry along its contour, according to the working project, a harbor will be organized with mooring place for yachts and boats. A hotel, cottages, a children's playground with an aqua park, an entertainment center, a sports complex, cafe, a restaurant, a park zone, a powerboating club and a parking lot for motor vehicles will be arranged on the periphery [11]. Social and economic development of the area, the complex development of mineral deposits and the need to organize within the city of Derbent of the objects of cultural-social and sports-recreation direction determine the water management reclamation of the previously mined-out space of a quarry.

The traditional approach to the reclamation of disturbed lands provides the choice of their restoration direction, depending on the subsequent use [12]. In practice, there are various examples of reclamation for the purpose of recreational complexes arrangement. The Aqua Park as a part of the landscape and recreation zone of the Shartashsky quarry near the city of Yekaterinburg is used year-round: in summer - a recreational zone, and in winter - a skating rink. When constructing the Tangua Park in Brazil, two old partially flooded quarries were used, located on its territory and connected by a 45 -meter tunnel. The multilevel observation deck, a cafe with well-groomed lawns and fountains are located at the top of a quarry.

The following requirements are specified to recreation zones with water objects [13]: compliance of water quality of a water object and the state of the territory with health requirements; existence or possibility of arranging the convenient and safe approaches to water; availability of access roads to the recreation zone; safe bottom relief; favorable hydraulic control; lack of possibility of adverse and dangerous processes [14-17]. In the improvement of the recreation zone of a quarry, it is necessary to observe the following requirements. When calculating the required area of the beach territory, it is necessary to 
proceed from the norm not less than 8 sq.m per a person for a beach on reservoirs. When calculating the area of the children's sector, it is necessary to proceed from the norm not less than 4 sq.m per one person. The bathing zone in the children's sector should have the bottom with a low gradient, with the prevailing depth of $40-50 \mathrm{~cm}$, but no more than $70 \mathrm{~cm}$. The following functional zones should be allocated on the beach territory: $40-60 \%-\mathrm{a}$ zone of recreation; the shadowing of the certain beach sites should be provided by shaded shelters, umbrellas, awnings, taking into account that at least up to $40 \%$ of vacationers will use them on the beach; $5-8 \%$ - a service zone; $10 \%$ - a sports zone; $20-40 \%-$ a landscaped zone; $5-7 \%$ - the children's sector; $3-5 \%$ - walkways. The comfortable conditions for vacationers in recreation zones will be created when fulfilling these requirements with reclamation of the previously mined-out space of quarries.

The water management direction of reclaiming the disturbed land assumes the construction of reservoirs of various application in a quarry depression, taking measures for prevention of landslides and stream-bank erosion, taking into account their complex use mainly for water supply, fish breeding, irrigation and recreational purposes. The formation of a beach on the bank of the previously mined-out space of a quarry requires particular knowledge in the field of hydraulic engineering. Thus, for this purpose, a quality of the local soil, the beach gradient, the linear dimensions of the site, the type of vegetation, parameters of depths and the reservoir slopes should be considered. At the same time, it is necessary to determine dumping thickness, carefully select the fraction and quality of sand, realize the activities for preservation and qualitative servicing the beach in the future. The transformation of the previously mined-out space of a quarry to the habitat of plants and the rest area of the population can be made in case of timely reclamation and landscaping of the flooded part.

\section{Methodological approach to the creation of a recreation zone in the quarry}

The mining areas that have lost their industrial function are being restored and turn into industrial tourism within the framework of a regional revival. In the process of transformation of abandoned, degrading mining landscapes into the areas attractive for tourism, as well as their reclamation and strengthening are favorable for the local society and the ore mining region. Development of recreational activities, intended for arranging the beaches, artificially created dunes, camping sites, sports grounds and small mooring place for yachts, as well as new forests with walking trails is supposed on the previously mined-out territories [18]. Swimming, fishing, boating, bicycling, windsurfing and hiking are entertaining activities in the zones of recreation.

In terms of reclamation of the previously mined-out quarry Břidla, there is an opportunity to diversify and stabilize its territory [19]. For this purpose, a technical modification and biological restoration of the selected site has been developed in detail, because these steps can be realized in the short term of 5-10 years. Forming and recreational use of the quarry has been planned, though the completion of industrial activity is an issue of a quite distant future. The whole Břidla quarry site after the completion of mining operations is included back into the protected landscape of the Moravian Crust. The development of the natural environment for this area will become a small nature reserve and the rest area of the population.

Reclamation of previously mined-out areas is an effective way to protect the environment in mining regions $[20,21]$. The substantiation of waste disposal technology in the mined-out space of Vostochnyi quarry is based on the analysis of hydrodynamic and hydrochemical descriptions of the project, laboratory studies of a backfilling interaction with quarry water and prediction of modeling the state changes in the course of a quarry 
refilling. Rehabilitation of the lands disturbed by mining operations, takes place in two stages. At the first stage, refilling of the mined-out space, bank slope work of a quarry and dumps, as well as levelling the ground should be performed. Further on, the waste placement in the previously mined-out spaces should solve a number of technological, ecological and rehabilitation problems. At the same time, withdrawal of lands, pollution of surface and subsurface water, prevention of air pollution are reduced, and, moreover, the landscape is restored for recreational purposes by means of reduced expenses on waste management.

The best example of the disturbed lands reclamation in Poland is the creation of regional recreation park named after George Zitek on the territories, which are strongly transformed by mining and metallurgical industry [22]. The area of 620 hectares has been transformed into a recreation park with such amusements as a zoo, a fair, a stadium, swimming pools, a planetarium, a park of heritage, a rose garden, a cableway, exhibition halls of forest reserves and green zones. An example of revival in Poland is the transformation of operated quarry in Podgórze (now a part of Krakow) into a city park, where an amphitheater and a nature reserve have been built in the former lime quarry in Kielce. All taken measures are the compensation to various inconveniences after the field mining operations and create opportunities for the social and economic development of municipal administrations and regions.

The responsibility for rational management of the field development and reclamation of the lands disturbed by mining operations is placed upon local authorities. The quarry operation has a serious impact on a nearby environment, disturbs a natural relief, water resources, soil, flora and fauna [23]. The legislation when conducting mining operations considers protection of the environment and justification of more rigorous restrictions, as well as the establishment of stricter ecological requirements. The abandoned quarries recovery has been practiced for several years in various regions of Greece. As a result, a wide range of rehabilitation solutions has been proposed that are used by local authorities for satisfaction of basic needs of the population, when creating the cultural and sports centers, open theaters, reforestation, and solving the most acute environmental problems. The gradual reclamation of previously mined-out quarry spaces with local assistance can promote the improvement of an environment quality in the vicinity of cities and can be included in regional development plans.

As a result of opencast mining of natural resources, irrespective of its scales, the terrain relief is transformed, the soil profile is disturbed, the state of water resources and flora is changed [24]. In these conditions, the cost of reclamation increases, because of noncompliance with the obligations of public authorities to ensure the state of the postindustrial territory. The lack of rational planning and the current reclamation at a stage of mining works is another reason [25]. It should be noted that filling the mined-out space with water provides opportunities for the use of disturbed lands for the recreational purposes. For this purpose, it is necessary to plan these activities with the territorial authorities and the local community at a rather early stage of mining operations.

The opencast mining of mineral deposits seriously changes the topography and physical conditions of the atmosphere and has an inverse impact on plant life, soil conditions, habitats of wild animals and water resources in the area of mining operations and adjacent vicinities. If the effective measures to reduce adverse environmental impacts are not taken, then the degradation of the nearby environment because of opencast mining operations can be irreversible [26]. In the developed countries, this problem finds a comprehensive solution as they have more rigorous and effective rules. The land reclamation is considered a continuous process during mining, hence, mining companies should prepare detailed plans for management of environment protection and use expensive nature protection technologies. As part of the project, hiking, cycling and horse riding routes for public rest, 
as well as the construction of four miles of trails have been proposed for recreational activities.

The former mining areas, which have lost their industrial function, are being restored and turned into the zones of industrial tourism within the framework of regional revival. The process of transformation of abandoned, degraded landscapes after mining operations into the areas of interest to tourism is an important problem for the authorities, technical specialists, tourism managers, concerned parties and the local population. The abandoned and depressed mining areas should be reclaimed, their transformation into the tourist zones after mining operations is designed to stimulate sustainable regional development. The existing mining and chemical areas, which have lost their industrial function are being rehabilitated as industrial tourism of heritage within the framework of regional revival. One of the ways to contribute to success of development plans for industrial heritage is to assess the economic, environmental, cultural and social impacts, which require drawing up structural plans in monetary value.

With timely reclamation of the lands disturbed by mining operations, society can eliminate the negative consequences of anthropogenic industrial activity [27]. Rehabilitation of the previously mined-out space of quarries can benefit the population of the territory and reduce the environmental impact of quarries on the nearby environment when creating a national park and luxury hotels, various public and private spaces, nature protection zones, an open-air theater and filming locations. The famous Groundscraper Hotel, located near the city of Shanghai, has the sports ground, a complex for water sports in the pool of the quarry, underwater restaurant and deep aquarium. The land rehabilitation of mined-out quarries is directed to arrangement of the disturbed sites in order to be suitable for new steady land use and improvement of social, economic and ecological conditions of the area.

Various methods of mined-out quarries recovery in England, which require reclamation, are considered. The rehabilitation ways have been developed, which are used to prepare a relief for vegetation growth, to ensure safety on site, and also for adaptation to the recreational purposes [28]. The use of these methods can improve the ecological quality of the land degraded as a result of the field mining operation. Various methods have been developed for stone quarries reclamation and are important when using safe, sustainable, ecologically rich and esthetically pleasant landscapes. Therefore, these methods are necessary to use in a combination when creating an interest by means of a variety of shapes and the nature of a relief. This can be achieved by selective treatment of various quarry parts with the purpose of reasonable use of scarce materials in the course of the territory reclamation. In the recreational lake, as well as in agriculture, different slopes of different quarry sites can be applied for adaptation to different uses.

Rehabilitation of the abandoned quarries can mitigate the effects of nearby environment destruction and satisfy social demand for improvement of a living quality in the city centers [29]. Therefore, the economic value is taken into account of remediation works using the basis of environmental economics of a previously mined-out quarry in the center of Athens. Restoring the disturbed territory creates important economic value, which can be useful to justify the environmental policy and to provide additional public funding. The projects for reclaiming the abandoned quarries in urban areas have particular advantages for creating landscaped and recreation areas. Thus, the benefits of restoring the abandoned urban quarries to local authorities, as well as to the Greek public, are proven. The assessments can be used to substantiate the decisions related to rehabilitation projects and the potential benefits of reclamation.

The rehabilitation plan or the program description should be made taking into account stage-by-stage approach to mining and inclusion of whenever possible timely land reclamation [30]. At the same time, the purpose should include rational land use and 
conservation of an environment of the neighboring territories, as well as the proposed use of the site after restoration. The land areas, intended to rehabilitation, should include successive stages or justification of a delay of remediation until the completion of operations. Rehabilitation after mining operations depends on the agreement with the landowner. These activities can include stabilizing of inactive quarry space and the borrowed areas with grass perennial plants, preservation of the soil, improvement of esthetic appeal by creation of the recreation zones, as well as an ability of the territory to maintain wildlife.

The purpose of reclamation is to prevent or minimize the negative impact on a nearby environment of disturbed lands after the completion of mining operations and to return the negatively affected areas to productive and long use by wildlife and people [31]. The reclaimed sites will be chemically and physically stable and will finally perform the same functions, as the adjacent virgin lands. A practical and beneficial approach is crucial when restoring the quarries for recreational purposes. With the use of the best management practices, the quarries will be restored by stabilizing the disturbed Earth surface that promotes natural vegetation recovery and the rehabilitation of disturbed lands.

The use of the above effective ways of reclaiming the previously mined-out space of quarries for the recreational purposes favors the creation of a comfortable recreation zone on the bank of the reservoir for the population of the nearby territory of mineral deposits development.

\section{Results and discussion}

The creation of recreation zones and the construction of other objects in the previously mined-out spaces of quarries should be motivated by both the state, and the subsoil user [32]. For this purpose, the legislative base is necessary to regulate the relations between the state, both the owner of a subsoil and the subsoil user, determining an order and conditions of assignment of the mined-out field for subsequent use. To do this, it is necessary to determine already at the design stage the direction of the field use after completion of its operation. Using the mined-out space for the recreational purposes should become the dominant direction of large cities development, allowing to improve the land use indicators.

In the beach area, three planned zones should be provided, various by their functional purposes: beach, the active holiday and quiet rest [33]. The beach area is an open space up to $30-40 \mathrm{~m}$ in width, intended for sunbathing, and is located immediately near the water line. This zone has the highest filling density. In the active rest zone located behind the beach, there are sites and grounds for volleyball, basketball, table tennis, and badminton. The width of this zone can range within the significant limits - from 15 to $40-50 \mathrm{~m}$, depending on the availability of free territory and the general planning solution for a coastal strip. The zone of quiet rest is intended for walks and rest in the shade, among green planting, which territory should occupy not less than $20 \%$ of all coastal strip. It is equipped with the rest sites, arbors, and walking paths. It is necessary to consider such planning solution of the beach territory as the most expedient, however, it is not always possible. First of all, the local conditions, the relief and area of the coastal strip, existence of green planting have a great influence on planning the beach. The most difficult thing is to achieve this on sea beaches with steep banks. The coastal territory of Sochi is an attractive zone for vacationers and local population, a zone where the important traffic artery runs; it is expedient to control the process of development and management of this territory, approaching this matter comprehensively, in order to create an environment capable to sustainable development in difficult hydrological and geological conditions.

The negative effects of mining and chemical quarries on the nearby environment can be overcome thanks to rehabilitation works on the disturbed territories. The works on land 
reclamation should be favorable for the enterprise and the preservation of the natural environment for the recreational purposes [34]. For the sustainable development of natural resources, it is necessary to meet all the requirements of the law and rules, before and after the mine field operation. Therefore, local authorities have to support the recovery works in these areas to protect habitats, which are exclusively endangered on previously mined-out land territory.

Effective use of the previously mined-out quarries located within the city allows restoring their spaces in the recreational direction for creation of nature reserves and wildlife areas, tourist and health-improving zones, sports and leisure centers, as well as the combined recreation zones [35]. The organization of recreation zones on the basis of previously mined-out quarries will allow to carry out the following: to create the friendly environment of the district and use comprehensively urban areas; to unite various commercial, communal and residential organizations, sports and cultural-educational institutions into sports and recreation complexes; to provide the working population of the area with new jobs, to contribute to the development of small and medium business, to increase the level of physical culture and health of the population, to attract the younger generation to a healthy lifestyle and sport.

The quarry after extraction of mineral resources becomes an interesting geological, morphological and horizontal object, without further research and anthropogenic modifications. Therefore, it can be presented for use as an object of ecotourism after reclamation of its space, as a convenient environment for tourists not only during normal quarry operation, but even during working time [36]. The general group tours of visitors transported immediately to the quarry with special services, despite quarry noise, dust, often a health risk. In order to use a quarry as an object of mining tourism, it is necessary to carefully and systematically investigate it in terms of anthropogenic geomorphology. For use of the territory of quarries as recreation areas, sports and entertainment activities, the nature reserve, it is possible to present them as quarries, as geo-parks, and also as an important paleontological and mineralogical areas.

When reclaiming and arranging the flooded quarries and in the course of dredging operation, it is necessary to create the flat and plane bottom. Subsequently, to use the reservoir for a long time without a considerable deterioration of water quality, its minimum depth should be not less than $2 \mathrm{~m}$ with a minimum seasonal level of water fluctuation [37]. The shape of the quarry slopes is influenced by its planned target use as a reservoir. In the reservoirs intended for swimming and rest, it is recommended to create more low gradients in comparison with the reservoirs used for fishing, rowing-sailing, or other purposes. The possible slopes profiles of artificial reservoirs in quarries are shown in Fig. 1. At the boundary of the water space, the slopes of a reservoir should be especially flat to prevent accidents on water and to provide development of vegetation serving for strengthening the coast. The steepness of the coast in this place should be not less than $\mathrm{m}=3$ at a distance not less than 1.5-2 m from the minimum water level, depending on the designed purpose of the entire reservoir or its part. Under the terms of works in deep quarries, the slopes, as a rule, are made steeper, with a slope inclination $m=1.5-2$. In such quarries, the slopes located above the water line, as a rule, are dry and more stable with a slope inclination $m=2$. Therefore, the slopes in deep quarries, located above the water line should have a slope inclination $m=2$ and more, and at high altitude they should be intercepted by berms with a minimum width of $3 \mathrm{~m}$ for each $5 \mathrm{~m}$ along the slope height. The upper edges of depressions along all slopes should be rounded for a smooth transition to the natural Earth surface. In order to give final shape, the slopes should be covered with a layer of soil removed before quarrying, with a thickness not less than $0.15 \mathrm{~m}$. The underwater slopes are also covered with soil in places of planting water vegetation. 


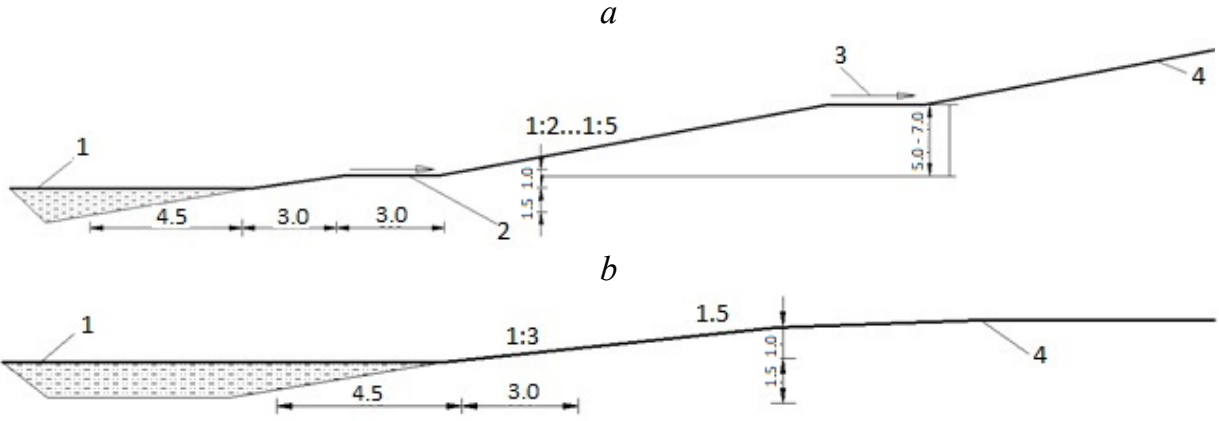

$c$

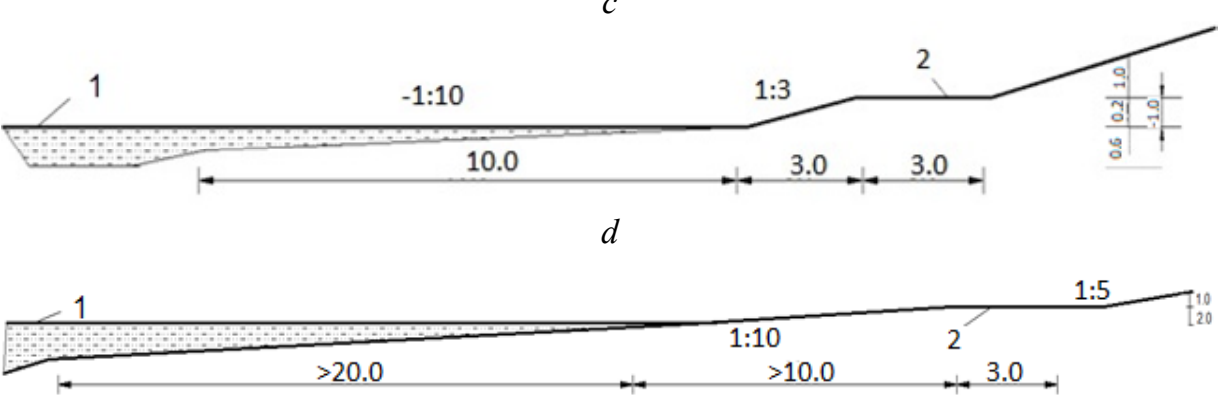

Fig. 1. Possible profiles of the slopes of artificial reservoirs formed in quarries (dimensions in $\mathrm{m}$ ): a and $\mathrm{b}$ - high and low above-water slopes of mine working; $\mathrm{c}$ - the shallow site with an underwater ledge and a low above-water slope; $\mathrm{d}$ - the sandy beach; 1 - the water level in a reservoir; 2 - a berm with a territorial road; 3 -intermediate berm; 4 - smooth intersection of a slope with terrain relief.

Having analyzed the modern principles of a technogenic relief formation and the methods for calculating its parameters, taking into account the requirements of geomorphology, the methodological approach has been developed to substantiate the landscape parameters for the reclamation of the previously mined-out space of the quarry for water and recreational purposes [38]. The parameters of the relief main forms have been scientifically substantiated when arranging a water and recreation zone in the previously mined-out space of the quarry with account of hydro-climatic conditions of the region and lithological structure of rocks of the basement. The parameters of the relief forms for reclamation works have been determined with account of forming the scientifically substantiated parameters of the reclaimed surface for the residual mine workings in the Tuchkovsky Works of Building Materials.

The coastal zone includes surface and underwater parts and is the interaction area of water and onshore. The scope and types of work for the coastal zone designing in the previously mined-out quarries intended for reservoirs, depend on the stage of water table in the created reservoir, the purpose of the coastline certain sites, the height of the coast and the composition of the rocks forming it and is determined in each case on the basis of an individual project [6]. The parameters of the coastal zone intended for swimming: the quarry flank is flattened with a slope of $1: 7$ up to a depth of $1.0 \mathrm{~m}$ of the reservoir and with a slope of 1:4 up to a depth of $1.7 \mathrm{~m}$, and these sites are covered with sand. This contour is adjoined with the beach area of $15-20 \mathrm{~m}$ wide (Fig. 2). The underwater part of a reservoir is covered with sand up to a depth of $2.5 \mathrm{~m}$. In the places allocated for swimming, the bottom of the reservoir should be with a gradual slope, not have ledges and holes, sharp stones, broken glass and waste. 
If the quarry freeboard is composed of soft rocks, then by height it should be divided by berms into separate ledges. The berm width is accepted equal not less than $1.5 \mathrm{~m}$ with reverse slope of 1:10. The lower berm is arranged at a height of $1.5 \mathrm{~m}$ from the water table, and the second is at a height of $5-7 \mathrm{~m}$. The slope inclination is accepted equal 1:2, except the lower one (Fig. 3). With the height of above-water part of a quarry flank, more than 3 $5 \mathrm{~m}$ along the upper quarry edge, a hill ditch or a rise is constructed, which prevents the slope from the superficial drain of atmospheric waters and a water erosion.

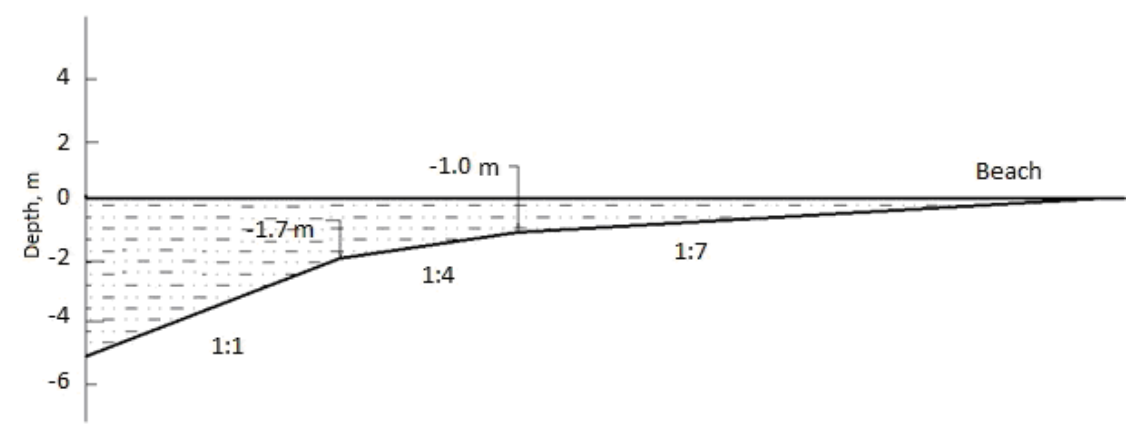

Fig. 2. Designing the beach area prior to the reservoir construction at a site of previously mined-out quarry.

In case of water management direction of reclamation, the reservoirs are created in depressions of the technogenic relief formed by mined-out space. The recreational direction of reclamation provides the organization of recreation zones, tourist centers, sports facilities, and parks on the disturbed lands [39]. The quarries of carbonate rocks are usually located near the large industrial centers, have a relatively small depth, and small volumes of overburden rocks.

This circumstance does not allow to completely fill the previously mined-out space with overburden rocks after the mine field completion. It complicates the subsequent their involvement in the sphere of economic and social activity.

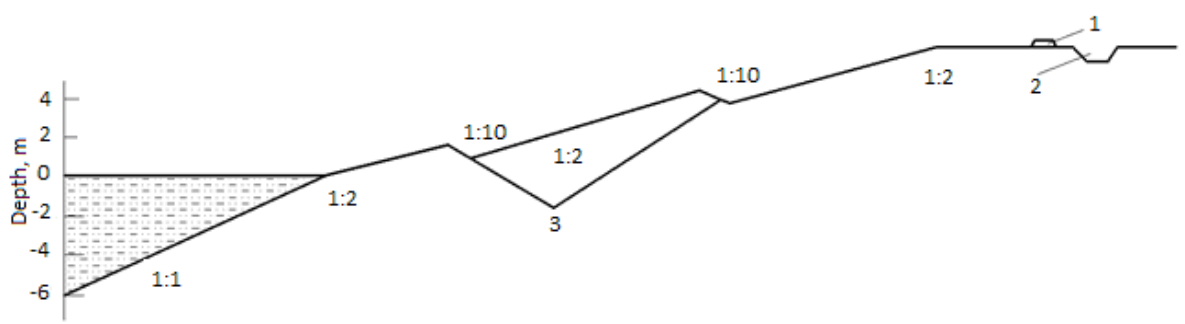

Fig. 3. A reservoir slope in soft rocks: 1 - water-retaining rise; 2 - hill ditch; 3 - berm (1.5 m).

In the case under consideration, there is a possibility to form the beach zone with the use of overburden rocks in areas where water line will run along the bottom of mine working with a small slope. The total length of a shallow zone will be about $40 \%$ of the reservoir perimeter [40]. Predicting the dynamics of water input and water output of the water balance equation depending on the degree of flooding the mined-out space allows to accurately determine the parameters of the created reservoir and to establish types and scope of works on the designing its coastline.

The direction of reclamation should provide the rational and comprehensive use of land resources of the area, the creation of the harmonic landscapes which satisfy the ecological, economic, esthetic, sanitary, and hygienic requirements with the greatest effect and the least 
expenses [41]. The use of the territory of the previously mined-out quarries to create sports and health-improving complexes for winter and summer sports, a healthcare centers based on the creation and development of the arboretum park and construction of a complex of sports facilities effectively influences the health of the population and state of environment.

Sayran Lake is of artificial origin, a popular rest area for Almaty residents. It is a reservoir created on the site of a former quarry by way of arrangement of a dam on the Bolshaya Almatinka River [42]. It is filled with water only in warm season. In winter, water is drained. The lake is located in the Almaty district Tastak, in the heart of the southern capital of the republic, and a park is located in the coastal zone. The area of Sayran Lake is 50 hectares, the artificial lake is capable to hold 2 million cubic meters of water and various sports take place there. The lake with a well-developed infrastructure, equipped beach areas in the eastern and western part, is a popular rest area for Almaty residents and guests of the city. The beach on the east bank appeared at the same time with the lake and today this historical rest area of citizens has well developed beach infrastructure (Fig. 4). For the comfort of vacationers, the paths of wood are laid, stationary umbrellas, changing stalls and the sun loungers are available. It is possible to play volleyball on the beach. The game zone is equipped for children.

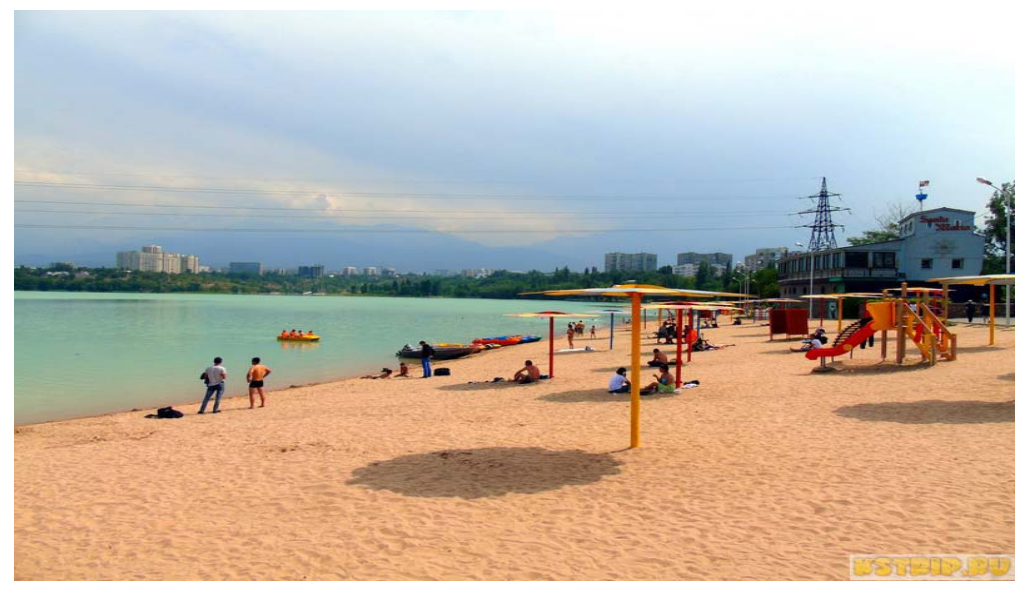

Fig. 4. The beach on the Sayran Lake.

The territory around the lake has been landscaped and reclaimed with account of the modern principles of a comfortable urban environment: the paths have been laid, the beach has been filled with sand, and a boat station has been organized. The pedestrian alleys surrounding a reservoir have been laid, there are jogging paths and cycling paths with a total length of $5 \mathrm{~km}$. In the upper part of the lake, there is a soccer and volleyball field. A pedestrian bridge is erected over the spectacular waterfall, from which it is possible to admire the rush of water flowing from under the Abay Avenue to the reservoir.

\section{Conclusions}

The close proximity of the settlements to the previously mined-out spaces of quarries requires the solution of the area improvement after the completion of opencast fields mining. One of the rational ways to recover the mined-out area after opencast mining operations is to use it for recreational purposes. In these conditions, the construction of cultural-social and sports-recreation complexes with the reclamation of the quarry coastal zone, with appropriate accounting of the described above rational methodical approaches to 
creation of a recreation area, in practice, favors to social and economic development of the ore mining area.

The development of design methods for reclaiming the previously mined-out quarry for recreational purposes includes performing different types of analysis and the optimal choice of the well-thought-out re-planning of the territory into the beach zones and active rest zones, sports-entertainment centers, that should comply with the ecological requirements and satisfy the expectations of society. The most effective way to improve the potential of land-use management is to create the favorable nearby environment for local population after completion of opencast mining operations.

This work was carried out within the framework of the Grant Financing Project of the Ministry of Education and Science of the Republic of Kazakhstan 2018/APO5131591.

\section{References}

1. GOST 17.5.1.02-85. Mezhgosudarstvennyy standart. Okhrana prirody. Zemli. Klassifikatsiya narushennykh zemel' dlya rekul'tivatsii.

2. Zemel'nyy kodeks Respubliki Kazakhstan. (2018). Zakon Respubliki Kazakhstan No. 151-VI. Vedomosti Parlamenta Respubliki Kazakhstan.

3. O nedrakh i nedropol'zovanii. (2017). Kodeks Respubliki Kazakhstan.

4. Ekologicheskiy kodeks Respubliki Kazakhstan No. 156-VI. (2018).

5. Kalybekov, T., Rysbekov, K., \& Zhakypbek, Y. (2015). Efficient land use in open-cut mining. New Developments in Mining Engineering 2015: Theoretical and Practical Solutions of Mineral Resources Mining, 287-291. https://doi.org/10.1201/b19901-51

6. Popov, I.I., \& Kalybekov, T. (2000). Marksheyderskoe delo. Marksheyderskie raboty pri gornotekhnicheskoy rekul'tivatsii narushennykh zemel'. Almaty: pechatnyy dom.

7. Gorova, A., Pavlychenko, A., Borysovs'ka, O., Krups'ka, L. (2013) The development of methodology for assessment of environmental risk degree in mining regions. Annual ScientificTechnical Colletion - Mining of Mineral Deposits, 207-209. https://doi.org/10.1201/b16354-38

8. GOST P 57446-2017. Nailuchshie dostupnye tekhnologii. Rekul'tivatsiya narushennykh zemel' $i$ zemel'nykh uchastkov. Vosstanovlenie biologicheskogo raznoobraziya. Moskva: Standart-inform.

9. Kalybekov, T. (2014). Izuchenie ispol'zovaniya narushennykh i rekul'tivirovannykh zemel' na otkrytykh razrabotkakh. In Mezhdunarodnyi Forum (pp. 364-370). Almaty: Kazakhskiy natsional'nyy tekhnicheskiy universitet.

10. Rysbekov, K., Huayang, D., Kalybekov, T., Sandybekov, M., Idrissov, K., Zhakypbek, Y., Bakhmagambetova, G. (2019). Application features of the surface laser scanning technology when solving the main tasks of surveying support for reclamation. Mining of Mineral Deposits, 13(3), 40-48. https://doi.org/10.33271/mining13.03.040

11. Musaev, N.M., Moseykin, V.V., \& Punevskiy, S.A. (2010). Vodokhozyaystvennaya rekul'tivatsiya kar'yerov Derbentskogo mestorozhdeniya izvestnyakov. Gornyy InformatsionnoAnaliticheskiy Byulleten', (5), 37-42.

12. Musaev, N.M., Moseykin, V.V., \& Punevskiy, S.A. (2010). Vodokhozyaystvennaya rekul'tivatsiya kar'yerov Derbentskogo mestorozhdeniya izvestnyakov. Gornyy InformatsionnoAnaliticheskiy Byulleten', (4), 39-45.

13. GOST 17.1.5.02-80. Okhrana prirody (SSOP). Gidrosfera. Gigienicheskie trebovaniya k zonam rekreatsii vodnykh ob'yektov. Moskva: IPK Izdatel'stvo standartov.

14. Chui, Y.V., Moshynskyi, V.S., Martyniuk, P.M., \& Stepanchenko, O.M. (2018). On conjugation conditions in the filtration problems upon existence of semipermeable inclusions. JP Journal of Heat and Mass Transfer, 15(3), 609-619.

15. Kuzlo, M.T., Moshynskyi, V.S., Martyniuk, P.M. (2018). Mathematical modelling of soil massif's deformations under its drainage. International Journal of Applied Mathematics, 31(6), 751-762. 
16. Malanchuk, Z.R. (2019). Substantiating parameters of zeolite-smectite puff-stone washout and migration within an extraction chamber. Naukovyi Visnyk Natsionalnoho Hirnychoho Universytetu, (6), 1-9.

17. Bomba, A., Tkachuk, M., Havryliuk, V., Kyrysha, R., Gerasimov, I., \& Pinchuk, O. (2018). Mathematical modelling of filtration processes in drainage systems using conformal mapping. Journal of Water and Land Development, 39(1), 11-15.

18. Mendes, I. (2013). Mining Rehabilitation Planning, Mining Heritage Tourism, Benefits and Contingent Valuation. SOCIUS Working Papers, (3).

19. Vilém, Jurek. (2014). Wildlife return at the quarry "Brílda". Possibilities of natural habitat restoration. Czech Republic: Brno.

20. Rybnikova, L.S., Rybnikov, P.A., \& Tarasova, I.V. (2017). Geoecological Challenges of ined-Put Open Pit Area Use in the Ural. Journal of Mining Science, 53(1), 181-190. https://doi.org/10.1134/s1062739117012006

21. Piwniak, G.G. et al. (2007). Limits to economic viability of extraction of thin coal seams in Ukraine. Technical, Technological and Economic Aspects of Thin-Seams Coal Mining International Mining Forum 2007, 129-132. https://doi.org/10.1201/noe0415436700.ch16

22. Uberman, R., \& Ostręga, A. (2012). Reclamation and revitalization of lands after mining activities. Polish achievements and problems. AGH Journal of Mining and Geoengineering, 36(2), 285-297.

23. Hagiou, E., \& Konstantopoulou, G. (2010). Environmental planning of abandoned quarries rehabilitation - a methodology. Bulletin of the Geological Society of Greece, (43), 1157-1164. https://doi.org/10.12681/bgsg.11290

24. Chudzik, W. (2012). The process of mined land reclamation in natural aggregate quarries exemplified by the sand and gravel quarry Debina Letowska. AGH Journal of Mining and Geoengineering, 36(1), 89-96.

25. Kalybekov, T., Rysbekov, K.B., Toktarov, A.A., Otarbaev, O.M. (2019). Underground mine planning with regard to preparedness of mineral reserves. Mining Informational and Analytical Bulletin, (5), 34-43.

26. Nazan Kuter. (2013). Reclamation of Degraded Landscapes due to Opencast Mining. London. https://doi.org/10.5772/55796

27. Anne Whiston Spirn. (2013). No Longer Just a Hole in the Ground. The Adaptive Re-Use of Resource Depleted.

28. Israel A. Legwaila, Eckart, Lange, \& John, Cripps (2015). Quarry reclamation in England: a review of techniques. Journal American Society of Mining and Reclamation, 4(2), 55-79. http://doi.org/10.21000/JASMR15020055

29. Damigos, D., \& Kaliampakos, D. (2003). Assessing the benefits of reclaiming urban quarries: a CVM analysis. Landscape and Urban Planning, 64(4), 249-258. http://doi.org/10.1016/s01692046(02)00243-8

30. Nico Pienaar. (2013). Road Building, Borrow Pits, Construction Material, Quarries: Affects on the Commercial Quarry Industry. Aggregate and Sand Producers Association of Southern Africa.

31. Borrow Pits and Quarries Management Plan. (2015). Meliadine Gold Project.

32. Kosolapov, A.I., Ptashnik, Yu.P., \& Ptashnik, A.I. (2013). Perspektivy ispol'zovaniya vyrabotannykh prostranstv kar'yerov dlya razmeshcheniya predpriyatiy zhizneobespecheniya krupnykh gorodov. Gornyy Informatsionno-Analiticheskiy Byulleten', (3), 83-86.

33. Zolotova, M.S. (2015). Sozdanie arkhitekturno-landshaftnoy sredy i blagoustroystvo vodookhrannoy pribrezhnoy polosy. Molodoy uchenyy, (11), 331-335.

34. Kaya, L.G., Yücedağ, C., Bingöl, B. (2017). Usage of ineffective mining quarries for recreational purposes: the case study of burdur city, turkey. The Journal of Graduate School of Natural and Applied Sciences of Mehmet Akif Ersoy University, (8), 184-190.

35. Voron Ye.A. (2012). Rekreatsionnoe napravlenie rekuletivatsii kareyerov, raspolozhennykh v promyshlennykh zonakh. Geotekhnichna Mekhanika, (103), 74-82. 
36. Hronček, P. (2015). Local quarries and how to use them in geotourism. Acta Geoturistica, 6(1), 11-20.

37. Smetanin, V.I. (2000). Rekul'tivatsiya i obustroystvo narushennykh zemel'. Moskva: Kolos.

38. Belousov, K.S. (2011). Obosnovanie parametrov rekreatsionnoy zony pri rekul'tivatsii kar'yera s ispol'zovaniem gidromekhanizirovannykh tekhnologiy. PhD Thesis. Moskva, Russia: MGGU.

39. Kosolapov, A.I., Plyutov, Yu.A., \& Nazarova, Ye.Yu. (2004). K voprosu obosnovaniya napravleniya ispol'zovaniya vyrabotannykh prostranstv karbonatnykh kar'yerov. Sovremennye naukoyemkie tekhnologii, (2), 67-68.

40. Tal'gamer, B.L., \& Korobkova, Ye.A. (2011). Obosnovanie rabot po prirodookhrannomu napravleniyu rekul'tivatsii vyrabotannogo prostranstva. Vestnik Irkutskogo Gosudarstvennogo Tekhnicheskogo Universiteta, 9(56), 79-82.

41. Kalybekov, T., \& Zhakypbek, Y. (2018). Izucheniye kriteriyev vybora napravleniy rekul'tivatsii narushennykh zemel' pri razrabotke mestorozhdeniy otkrytym sposobom. Vestnik Kazakhskogo Nauchno-Issledovtel'skogo Tekhnicheskogo Universiteta im. K.I. Satpaeva, (4), 39-44.

42. Ozero Sayran (vodokhranilishche Sayran). Almaty. (2016). 